\title{
Epidural ve paravertebral apseler ile seyreden bruselloz olgusu
}

\section{Epidural and paravertebral abcesses in a case of brucellosis}

\author{
Duygu ÇERÇiOĞLU', Çiğdem Ataman HATiPOĞLU', Salih CESUR*1, Esra YÜKSEKKAYA', Haydar ÇELIK², \\ Kader DOĞAN', Esra Kaya KILIÇ' ${ }^{1}$ Ayşe BÜYÜKDEMIRCi'1, Sami KINIKLI', Mehmet Akif BAYAR²
}

'Ankara Eğitim ve Araştırma Hastanesi, Enfeksiyon Hastalıkları ve Klinik Mikrobiyoloji Kliniği, Ankara/Türkiye

${ }^{2}$ Ankara Eğitim ve Araştırma Hastanesi, Beyin Cerrahisi Kliniği, Ankara/Türkiye

\section{Öz}

LBruselloz pek çok organ ve sistemi tutabilen Türkiye'de endemik olarak görülebilen zoonotik bir infeksiyondur. Brusellozun başlıca tutulum yaptığı sistemler retiküloendoteliyal sistem ve iskelet-kas sistemidir. İskelet- kas sistemi tutulumu brusellozun en yaygın komplikasyonu olmasına rağmen, brusellozlu hastalarda paravertebral apse ve epidural apse birlikteliği oldukça nadirdir. Bu yazıda, bruselloza bağlı olarak epidural ve paravertebral apse gelişen, cerrahi ve antimikrobiyal tedavi uygulanan 52 yaşında bir erkek hasta sunularak literatür gözden geçirilmiştir.

Anahtar Kelimeler: Bruselloz, epidural apse, paravertebral apse, olgu sunumu

\section{ABSTRACT}

Brucellosis is a zoonotic infection, endemic in Turkey, which can involve many organs and systems. Brucellosis mainly involves the reticuloendothelial system and the skeletal-muscle system. Although skeletal-muscle system involvement is the most common complication of Brucellosis, paravertebral abscess associated with epidural abscess in patients with Brucellosis is rather uncommon. This article presents the case of a 52-year-old male patient that suffered epiduraland paravertebral abscess due to Brucellosis, and received surgical and antimicrobial treatment, followed by a literature review.

Key words: Brucellosis, epidural abscess, paravertebral abscess, case report

Sorumlu Yazar*: Salih Cesur, Ankara Eğitim ve Araştırma Hastanesi, Enfeksiyon Hastalıkları ve Klinik Mikrobiyoloji Kliniği, Ulucanlar Cad. Altındağ, Ankara, Türkiye

E-mail: scesur89@yahoo.com

Received 23.06.2017 accepted 01.03.2018

Doi: $10.18663 /$ tjcl.323436 


\section{Giriş}

Brusellozis ülkemizde ve dünyada belirli bölgelerde endemik olarak görülebilen zoonotik infeksiyonların başında gelmektedir. Bruselloz başlıca; infekte hayvanın pastörize edilmemiş süt ve süt ürünlerinin tüketimi, hastalıklı hayvanların sekresyonları ile temas, bazen de laboratuvarda yapılan mikrobiyolojik işlemler esnasında bulaşabilir (1).

Bruselloza bağlı mortalite oranı düşük olmasına rağmen morbidite oranı yüksektir.

Brusellozda en sık görülen komplikasyonların başında iskelet -kas sistemi komplikasyonları yer almaktadır . Bruselloza bağlı sakroileit ve spondilit gelişimi sık görülen komplikasyonlardır (1-3 ) Spondilit brusellozun erişkinlerde en sık ve en önemli osteoartiküler tutulum şeklidir (2). Özellikle uygun tedavi edilmeyen ileri yaştaki hastalarda spondilite bağıı olarak ciddi komplikasyonlar gelişebilir. Paravertebral apseler sıklıkla spondilite sekonder olarak gelişir (1). Bu yazıda bruselloza bağlı olarak hem paravertebral apse hem de epidural apse gelişen hayvancılıkla uğraşan 52 yaşında bir erkek olgu sunuldu.

\section{Olgu}

Elli iki yaşında erkek hasta yedi ay önce disk hernisi nedeniyle opere edilmişti. İki hafta önce bel bölgesinde gelişen ağrı , operasyon yerinde şişlik ve akıntısı olan hasta Beyin Cerrahi servisine yatırıldı. Fizik muayenesinde ateşi yoktu, lomber bölgede hassasiyet mevcuttu. Hastanın yapılan lomber manyetik rezonans görüntüleme (MRG)'sinde L3-L4 vertebralar posteriorunda, kraniokaudal uzunluğu $45 \mathrm{~mm}$, ön arka çapı 5 $\mathrm{mm}$ ve transvers uzunluğu $20 \mathrm{~mm}$ boyutlarında epidural apse ile L3-L5 vertebralarda paravertebral apseler saptandı (Resim ). Hasta Beyin Cerrahisi kliniğince opere edilerek apse drenajı yapıldı. Hastanın apsesine yönelik ampirik olarak ampisilinsulbaktam (SAM) tedavisi başlandı. İntraoperatif alınan apse kültüründe üreme olmadı. Mikroskopik incelemede yoğun lökosit görüldü, tüberküloz yönünden yapılan mikroskopik incelemede aside dirençli basil görülmedi. Epidural apse etiyolojisine yönelik yapılan tetkikler sonucunda hastada brusella Rose- Bengal boya testi pozitif olarak saptandı. Standart tüp aglütinasyon testi $1 / 640$, Coombs aglütinasyon testi $1 / 2560$ ve 2-merkaptoetanol testi $1 / 320$ titrede pozitif olarak rapor edildi. Hastanın anamnezinden taze peynir tüketmediği ancak hayvancılıkla uğraştığı ve hayvanların düşük yaptığı, ancak ğrenildi. Laboratuvar incelemesinde; kan lökosit sayısı 9100/ $\mu \mathrm{L}$, eritrosit sedimentasyon hızı $19 \mathrm{~mm} / \mathrm{sa}$ ve C-reaktif protein düzeyi $3,1 \mathrm{mg} / \mathrm{dL}$ ( $\mathrm{N}: 0-5 \mathrm{mg} / \mathrm{dL}$ ) olarak tespit edildi. Enfeksiyon Hastalıkları kliniğine yatırılan hastada yatışının 4.gününde bruselloz tanısı konarak doksisiklin ve rifampisin tedavisi başlandı. Ampirik başlanan SAM tedavisine piyojenik apse de olabileceği düşünerek devam edildi. Operasyondan bir hafta sonra, bruselloz tedavisinin beşinci gününde hastanın operasyon bölgesinde seropürülan akıntısı olması üzerine, nozokomiyal cerrahi alan infeksiyonu düşünülerek kültür alındı. Ampisilin-sulbaktam tedavisi kesilerek, piperasilin-tazobaktam tedavisine geçildi. Kan lökosit sayısı 7500/ $\mathrm{LL}$, eritrosit sedimentasyon hızı $23 \mathrm{~mm} / \mathrm{sa}$ ve C-reaktif protein düzeyi $28 \mathrm{mg} / \mathrm{dL}$ olarak saptandı. Kanlı agar ve EBM agar besiyerlerinde üreme olmadı. Akıntıdan BACTEC (Becton, Dickinson and Company, USA) otomatize kan kültür sitemine yapılan ekimde Brucella türleri (spp.) üremesi oldu. Kültürde başka mikroorganizma üremediğinden cerrahi alan enfeksiyonu olmadığı düşünüldü ve piperasilin-tazobaktam tedavisi yedi güne tamamlanarak kesildi. Bruselloz tedavisi ile yara yerindeki akıntısı gerileyen hasta, tedavisinin üçüncü ayında kontrole gelmek üzere taburcu edildi.

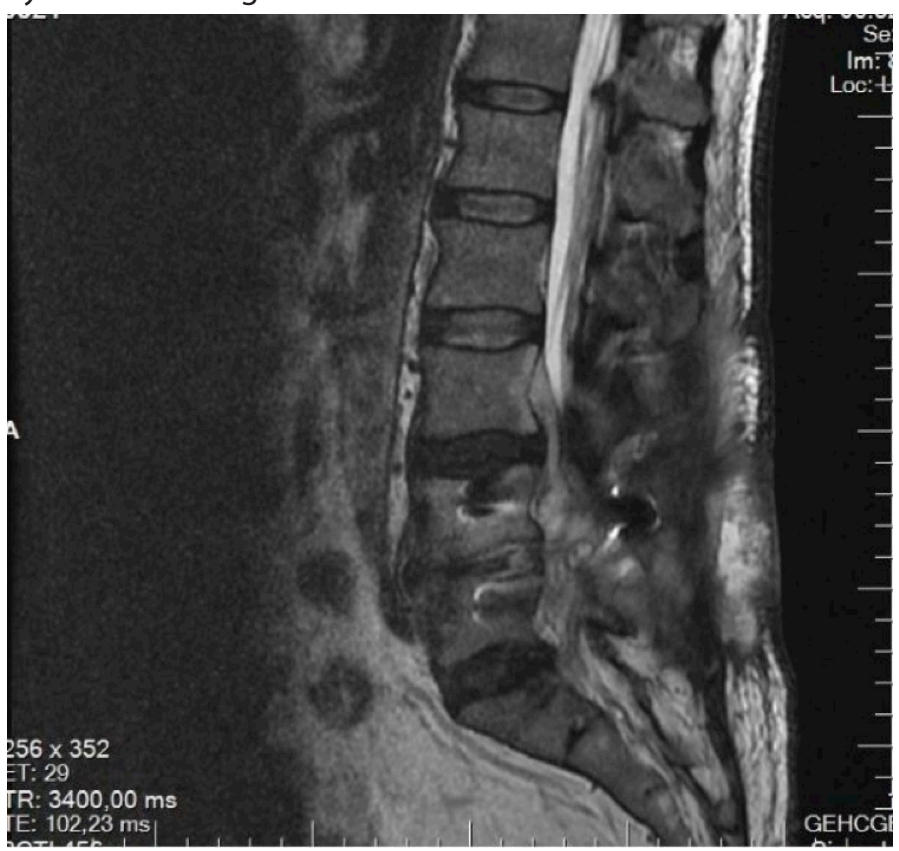

Resim. Brusellozlu hastada MRG'de paravertebral ve epidural apseler

\section{Tartışma}

Brusellozda osteoartiküler bulgular olguların yaklaşı \%20 -40 'ında görülür. Spondilodiskit kemik ve eklem tutulumunun en ağır formudur (1-3).

Bruselloza bağlı vertebra tutulumunda, vertebra korpusu ve intervertebral aralık en sık tutulan bölgelerdir. Bruselloza bağlı spondilodiskit veya diskitle birlikte epidural apse formasyonu sıklıkla ileri yaş hastalarda ve nadiren görülür.

Spinal apse ve spondilodiskitlerin ayıııcı tanısında tüberküloz ve bruselloz gibi kronik seyir gösterebilen bakteriyel infeksiyon etkenleri akılda tutulmalıdır (2-5). Bruselloza bağlı vertebra tutulumunda en sık tutulan bölge lomber vertebradır. Erken klinik bulgular bölgesel bel ağrısıdır ve olguların \%10-43'ünde nörolojik tutulum görülebilir. Bruselloza bağlı spondilodiskit ayırıcı tanısında, omurga tüberkülozu, pyojenik bakteriyel vertebra osteomiyelitleri, fıtıklaşmış disk ve metastatik 
lezyonlar ile ayırıcı tanı yapılmalıdır. Tüberküloza bağlı vertebra tutulumunda kemik yıkımı daha erken ve daha hızlı gelişir. Tüberkülozda paravertebral apse ve vertebra çökmesi daha yaygın olarak görülür (4).

Erdem ve ark.(5) 341 tüberküloz spondilodiskit, 327 brusella spondilodiskit hastası olmak üzere toplam 641 spondilodiskitli hastayı karşılaştırdıkları çok merkezli bir çalışmada; paravertebral, epidural ve psoas apse formasyonu ile birlikte vertebral korpus yüksekliği ve kalsifikasyonunun tüberküloz spondilodiskitinde (TBS) brucella spondilodiskitinden (BSD) daha fazla olduğunu bildirmişlerdir. Aynı çalışmada cerrahi girişim, motor kayıp, nörolojik defisit ve paralizi sıklığı ile mortalite oranları TBS'li olgularda BSD olgularına oranla daha fazla görülmüştür. Sunduğumuz olguda MRG'de L3-L4 arasında epidural, L3-L5 arasında ise paravertebral apseler saptandı. Olgumuzda başlangıçta pyojenik veretebral apseye yönelik başlanan ampirik olarak başlanan SAM tedavisine yanıt alınmadı. Apse materyalinden yapılan mikrobiyolojik incelemede tüberküloz basili saptanmaması, bruselloz yönünden incelemede brusella aglütinasyon testlerinin pozitif olması ve ameliyat bölgesindeki akıntı örneğinden Bactec kan kültür şişesine yapılan ekimde Brucella spp. bakterinin üremesi ile kesin tanısı konuldu.

Mehanic ve ark.(6) Saraybosna'da 120 brusellozlu hastada yaptıkları çalışmada osteoartiküler tutulumu 69 hastada saptarken, spondiliti olguların \%60.6'sında saptanmışlardır,spondilit saptanan olguların 9'unda ise paravertebral ve paraspinal apse bildirmiştir.

Eren ve ark. (7) bruselloza bağlı olarak spondilodiskit ve paravertebral apse gelişen iki olgu bildirimişlerdir. Olguların ilkinde perkütanöz apse drenaji ve bruselloza yönelik antimikrobiyal tedavi ile paraspinal apse tedavi edilirken, ikinci olguda spondilodiskit yagın ve apse büyük ve septalı olduğundan iğne drenajı ile yanıt alınmazken, perkütanöz kateter drenajı ve antibiyotik tedavisi ile yanıt alınmıştır. Olgumuzda paraspinal apse boyutlarının büyük olması ve beraberinde epidural apse de olması nedeniyle hastaya apseyi boşaltmak için cerrahi girişim uygulanmıştır.

Malavolta ve ark (8). ateş, halsizlik, miyalji , sırt ağrısı ve yürüme güçlüğü olan 45 yaşında bir kadın hastada bruselloza bağlı paraspinal apse bildirmişlerdir. Hastada kan kültürü ve apse dokusundan alınan biyopsi materyalinde kültürde üreme saptanmazken, tanı bruselloza yönelik serolojik testlerle konmuştur. Sunduğumuz olguda hastada yürüme güçlüğü ve sırt ağrısı semptomları mevcuttu. Olgumuzda spinal apse drenaj işleminin yapıldığı bölgedeki akıntıdan alınan örneğin BACTEC otomatize kan kültür sitemine yapılan kültüründe Brucella bakterisi izole edilmiştir,aynı materyalin kanlı agar ve EMB agar besiyerine yapılan ekimlerinde ise üreme saptanmamıştır. Sunduğumuz olguda bruselloz kesin tanısı, etkenin operasyon bölgesinden alınan örnekten izole edilmesi , bruselloza yönelik yapılan serolojik testlerin pozitif saptanması ile kondu.

Cesur ve ark. (9) 42 yaşında bir erkek hastada paravertebral apse ve orşit birlikteliği rapor etmişlerdir. Olgunun tanısı kan kültüründen etkenin izole edilmesi ve bruselloza yönelik serolojik testlerden standart tüp aglütinasyon testi pozitifliği ile konmuştur. Olgu üç ay süreli antibiyotik tedavisi ile cerrahi girişim uygulanmaksızın tamamen düzelmiş̧tir.

Sonuç olarak, ülkemiz gibi brusellozun endemik olduğu bölgelerde paravertebral ve/veya epidural apse saptanan olgular mutlaka bruselloz yönünden de araştırılmalıdır. Bakterinin katı besiyerlerinde kültürden üretilmesi zor ve uzun zaman aldığından, olgumuzda olduğu gibi klinik materyalin BACTEC vb. otomatize kan kültür sistemlerine ekilmesi durumunda etkenin izolasyon şansı artmaktadır.

\section{Çıkar çatışması / finansal destek beyanı}

Bu yazıdaki hiçbir yazarın herhangi bir çıkar çatışması yoktur. Yazının herhangi bir finansal desteği yoktur

\section{Kaynaklar}

1. Young EJ. Brucellosis. Mandell, Douglas and Bennet's Principles and Practice of Infectious Diseases, Mandell, Douglas and Bennet (eds), 7 th edi, Churchill Livingstone ,Pheladelphia, 2010; 2921-295.

2. Boyaci A, Boyaci N, Tutoglu A, Dokumaci DS. Spinal epidural abscess in brucellosis. BMJ Case Rep 2013. doi:10.1136.

3. Colmenero J. D. Clinical Findings, Therapeutic Approach, and Outcome of Brucellar Vertebral Osteomyelitis Clinical Infectious Diseases 2008; 46: 426-33.

4. Meriç Enercan, Çağatay Öztürk, Sinan Karaca, Azmi Hamzaoğlu. Omurga enfeksiyonları. Türk Ortopedi ve Travmatoloji Birliği Derneği Dergisi 2011; 10: 245-57.

5. Erdem H, Elaldi N, Batirel A et al. Comparison of brucellar and tuberculous spondylodiscitis patients: results of the multicenter "Backbone-1 Study. Spine J 2015; 15: 2509-17.

6. Mehanic S, Baljic R, Mulabdic V, Huric-Jusufi I, Pinjo F, TopalovicCetkovic J, Hadziosmanovic V. Osteoarticular manifestations of brucellosis. Med Arch 2012 ;66: 24-26.

7. Eren S, Büyükavci M, Ezirmik N, Ertek M. Spinal Brucellosis with Paraspinal Abscess Formation Treated with CT Guided Percutaneous Abscess Drainage. Interv Neuroradiol 2004; 10: 329-34.

8. Malavolta N, Frigato M, Zanardi M, Mule R, Lisi L, Gnudi S, Fini M. Brucella spondylitis with paravertebral abscess due to Brucella melitensis infection: a case report. Drugs Exp Clin Res 2002; 28: 95-98.

9. Cesur S, Ciftçi A, Sözen TH, Tekeli E. A case of epididymo-orchitis and paravertebral abscess due to brucellosis. J Infect 2003; 46: 251-3. 